\title{
The Effect of Interferon and Acute Appendicitis Infection on the Course of COVID-19 Disease
}

\author{
Ali Ahmadi* \\ Department of Biological Sciences and Technologies, Islamic Azad University, Iran
}

\section{LETTER TO EDITOR}

Dear Editor,

Major advances were made in the treatment of patients with chronic viral infections in the late 1990s and early 2000s. Combined interferon plus ribavirin (RBV) and pegylated interferon plus RBV, depending on the HCV infection genotype, increase the fixed virulence rate (SVR) from 5 to $40-80$ [1]. It is also associated with acute appendicitis as one of the most important causes of immediate abdominal surgery in the world. Many viral infections can lead to lymph node hyperplasia, which can cause intestinal obstruction. Some epidemiological studies have shown an association between appendicitis and viral respiratory infections [2,3]. According to studies in the literature, the results indicate that acute appendicitis is a rare complication of infectious mononucleosis (IM) that should be considered as a possible cause of persistent abdominal pain in a patient with IM. The study was conducted by searching for keywords in reputable databases such as interferon, acute appendicitis, and coronavirus infection in Google Scholar, Pub Med. Given that the outbreak of coronavirus in 2019 (COVID-19) originated in China [3]. According to the World Health Organization and epidemiological studies, more than $107,500,000$ people worldwide have been infected with the disease so far, and more than three million people have died. To the human family of Coronaviridae viruses, now known as Acute Respiratory Syndrome, Coronavirus 2 (SARS-CoV-2) research has documented the presence of a positive RNA virus with a diameter of 60 to $140 \mathrm{~nm}$ and a spike. A prominent feature of the virus family has reached all over the world [2].

Also, to report information in the literature on the frequency, symptoms, types of antibiotics, duration, and effectiveness in patients with Quid-19, about nineteen clinical studies included data reports from 2834 patients. The average rate of antibiotic use was $74.0 \%$. Half of the studies reported a common infection or bacterial complication. In recent cases, at least 17.6 of the patients receiving antibiotics had a secondary infection [1,4]. However, further research has shown that the virus is transmitted to humans through the virus-containing cough drops and sneezes by infected or asymptomatic but infected people. Subjects [5]. Also, in terms of the genome sequence, 75 to 80 are identical to SARS-CoV. Therapeutic agents include plasma therapy, which is the best way to improve the recovery of patients with the disease to control the prevalence of COVID-19 [6]. Early detection and reduction of close contact is the best way to prevent disease and reduce secondary infections among medical staff. Knowing the genome sequence facilitates rapid detection of the virus. The rapid response of China's clinical and scientific public health associations facilitates an understanding of clinical diseases and an initial understanding of the epidemiology of infection. Given all these efforts, the exact role of viral infections in acute appendicitis is unclear. Research has shown that some viruses associated with acute appendicitis include influenza virus, measles virus (MV), dengue virus (DFV), human immunodeficiency virus (HIV), and human herpesviruses (EBV, VZV, HSV, CMV), Adenovirus and rotavirus. These viruses are thought to cause lymphoid hyperplasia, resulting in intra-abdominal obstruction. It is also suggested that they are responsible for the enlargement of the mesenteric lymph nodes. In addition to viruses, other organisms such as Mycobacterium tuberculosis are also found in HIV patients with acute appendicitis, indicating the effect of MTB while HIV weakens the immune system. Further research is needed to understand the pathophysiology and pathogenesis of viral infections in appendicitis [7-9].

\section{REFERENCES}

1. Atkin C, Kamwa V, Reddy-Kolanu V, Parekh D, Evison F, et al. (2021) The changing characteristics of COVID-19 presentations: A regional comparison of SARS-CoV-2 hospitalized patients during the first and second wave. Acute Med 20(2): 92-100.

2. Sohrabi C, Zaid A, Niamh ON, Mehdi K, Ahmed K, et al. (2020) A review of the 2019 novel coronavirus (COVID-19). Int J Surg 76: 71-76.

3. Gralinski LE, Menachery VD (2020) Return of the coronavirus: 2019nCoV. Viruses 12(2): 135.
Quick Response Code:

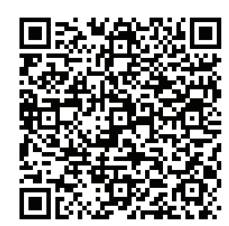

Address for correspondence: Ali Ahmadi, Student, Department of Biological Sciences and Technologies, Islamic Azad University Sari Branch, Iran

Received: September 21, $2021 \quad$ Published: September 29, 2021

How to cite this article: Ali A. The Effect of Interferon and Acute Appendicitis Infection on the Course of COVID-19 Disease. 2021- 3(5) OAJBS.ID.000324. DOI: 10.38125/OAJBS.000324 
4. Chedid M, Rami W, Elie H, Nabil C, Gebrael S. et al. (2021) Antibiotics in treatment of COVID-19 complications: a review of frequency, indications and efficacy. Journal of Infection and Public Health 14(5): 570-576.

5. Chen SJ, Wang SC, Chen YC (2020) Novel antiviral strategies in the treatment of COVID-19: A review. Microorganisms 8(9): 1259.

6. Yavuz S, Ünal S (2020) Antiviral treatment of COVID-19. Turk J Med Sci 50(SI-1): 611-619.
7. Wu A, Yousong P, Baoying H, Xiao D, Xianyue W, et al. (2020) Genome composition and divergence of the novel coronavirus (2019-nCoV) originating in China. Cell Host Microbe 27(3): 325-328.

8. Spaan WD, Cavanagh, Horzinek M (1988) Coronaviruses: structure and genome expression. Journal of General Virology 69(12): 2939-2952.

9. Peiris J, Lai ST, Poon LLM, Guan Y, Yam LYC, et al. (2003) Coronavirus as a possible cause of severe acute respiratory syndrome. The Lancet 361(9366): 1319-1325. 